\title{
Ocena jakości aparatury rentgenowskiej używanej w pracowniach mammograficznych $w$ realizacji badań przesiewowych raka piersi u kobiet w latach 2007 i 2011 w Polsce
}

\author{
Ewa Fabiszewska, Iwona Grabska, Katarzyna Pasicz, \\ Witold Skrzyński, Wojciech Bulski
}

Wstęp. Celem pracy było sprawdzenie, czy po czterech latach od wprowadzenia w Polsce systemu kontroli jakości przesiewowych badań mammograficznych nastąpiła poprawa stanu aparatury mammograficznej i czy wzrósł poziom realizacji testów podstawowych i specjalistycznych tej aparatury.

Materiał i metody. Materiał stanowiły protokoły pokontrolne sporządzone przez fizyków z 16 Wojewódzkich Ośrodków Koordynujących. Metody przeprowadzonych kontroli były oparte głównie na wymaganiach europejskich. W niniejszej pracy porównano wyniki dotyczące realizacji testów specjalistycznych, podstawowych i w nadzorze dla 293 mammografów w 2007 r. i 396 - w 2011 r.

Wyniki. W 2011 r. w porównaniu z rokiem 2007 odnotowano spadek liczby pracowni z systemem analogowym, dla których testy podstawowe były wykonywane nieprawidłowo lub niewykonywane w ogóle. Wzrósł udział pracowni mammograficznych z systemem analogowym, dla których zaakceptowano wyniki testów w nadzorze. W roku 2011 nastąpił spadek maksymalnej oraz średniej wartości średniej dawki gruczołowej (AGD) dla ekspozycji fantomu z PMMA o grubości 4,5 cm. Porównanie wyników kontroli wykonanych w 2011 roku dla trzech grup systemów mammograficznych (analogowych, ucyfrowionych i cyfrowych) pokazuje, że wymagań nie spełniają najczęściej systemy ucyfrowione, charakteryzując się przy tym jednocześnie najwyższą średnią wartością AGD.

Wnioski. Po czterech latach od wprowadzenia w Polsce systemu kontroli jakości przesiewowych badań mammograficznych nastąpiła znacząca poprawa stanu aparatury mammograficznej oraz wzrósł poziom realizacji testów podstawowych i specjalistycznych tej aparatury. Konieczne jest jednak jak najszybsze wprowadzenie w Polsce odpowiednich uregulowań prawnych dotyczących kontroli jakości mammograficznych systemów cyfrowych i ucyfrowionych w celu umożliwienia kompleksowej i rzetelnej oceny wszystkich pracowni mammograficznych w Polsce.

\section{Assessment of mammography equipment quality in mammography screening facilities} in 2007 and 2011 in Poland

Introduction. The purpose of this study was to assess whether over the four year period 2007-2011 after the implementation of the quality control program for mammography screening examinations in Poland, the quality of the mammography equipment improved and whether the quality level of basic and advanced tests performed at these facilities increased.

Material and methods. The material for this study comprised control protocols from 2007 and 2011, prepared by the physicists from 16 Regional Coordinating Centres. The control methodology was mostly based on European Union recommendations. In this paper, the results of performing advanced, basic and supervising tests for 293 mammography units in 2007 and 396 in 2011 were compared.

Zakład Fizyki Medycznej

Centrum Onkologii — Instytut im. Marii Skłodowskiej-Curie w Warszawie 
Results. In 2011, the number of facilities with analogue mammography units for which the basic tests were performed incorrectly or not performed at all, decreased in comparison to 2007. There was an increase in the number of facilities with analogue mammography units for which the results of supervising tests were acceptable. In 2011 the maximum and mean values of average glandular dose (AGD) for $4.5 \mathrm{~cm}$ thick PMMA phantom decreased. Comparison of the quality control results performed in 2011 for three types of mammography units (analogue, computed radiography and digital radiography) revealed that the computed radiography units fail the tests most often and yield the highest AGD values.

Conclusions. Over the four year period after the implementation of the quality control system for mammography screening in Poland, the quality of the mammography equipment significantly increased, and also the level of basic and advanced tests performed at these polish facilities improved. However, adequate legal regulations for quality control systems for DR and CR units is urgently needed in order to implement a comprehensive and reliable evaluation of all mammography facilities in Poland.

NOWOTWORY Journal of Oncology 2014; 64, 2: 119-128

Słowa kluczowe: kontrola jakości, mammografia, radiografia cyfrowa

Key words: quality control, mammography, digital radiography

\section{Wstęp}

W Polsce od roku 2007 prowadzone są na mocy umowy z Ministerstwem Zdrowia kontrole jakości badań mammograficznych wykonywanych w ramach „Populacyjnego Programu Wczesnego Wykrywania Raka Piersi”. Kontrole te są corocznie wykonywane przez fizyków z szesnastu Wojewódzkich Ośrodków Koordynujących (zwanych dalej WOK-ami). Metodyka kontroli jest ustalana przez Centralny Ośrodek Koordynujący Populacyjne Programy Wczesnego Wykrywania Raka Piersi oraz Profilaktyki i Wczesnego Wykrywania Raka Szyjki Macicy (zwany dalej COK) z siedzibą w Centrum Onkologii — Instytucie im. Marii Skłodowskiej-Curie w Warszawie. W 2007 r. za punkt wyjścia do opracowania zakresu i metod kontroli pracowni mammograficznych wykonujących badania przesiewowe przyjęto Uchwałę Rady Ministrów Nr 47/2006 [1], w której zapisano, że w realizacji programów przesiewowych w Polsce powinno się dążyć do spełnienia wymagań Komisji Europejskiej [2, 3]. Przy ustalaniu metodyki kontroli pracowni mammograficznych w 2007 roku uwzględniono Rozporządzenie Ministra Zdrowia z dnia 25 sierpnia 2005 roku w sprawie warunków bezpiecznego stosowania promieniowania jonizującego dla wszystkich rodzajów ekspozycji medycznych [4] oraz Rozporządzenie Ministra Zdrowia z dnia 21 sierpnia 2006 roku w sprawie szczegółowych warunków bezpiecznej pracy z urządzeniami radiologicznymi [5]. W 2011 roku, opracowując metodykę, uwzględniono znowelizowane Rozporządzenie Ministra Zdrowia z dnia 18 lutego 2011 roku w sprawie warunków bezpiecznego stosowania promieniowania jonizującego dla wszystkich rodzajów ekspozycji medycznych [6] oraz wymagania Narodowego Funduszu Zdrowia [7].

W latach 2008 i 2009 kontrolą w Polsce objęto tylko te pracownie mammograficzne, które uzyskały najniższą ocenę w roku poprzedzającym kontrolę, oraz te placówki, które dopiero włączono na listę realizatorów badań przesiewowych. W latach 2007, 2010 i 2011 skontrolowano wszystkie pracownie mammograficzne wykonujące badania przesiewowe w Polsce.

Autorzy niniejszej pracy postanowili porównać wyniki kontroli przeprowadzonych w roku 2007 i 2011, czyli po czterech latach od wprowadzenia w Polsce systemu kontroli jakości przesiewowych badań mammograficznych. Porównanie to miało na celu sprawdzenie, czy nastąpiła poprawa stanu aparatury mammograficznej stosowanej do badań przesiewowych oraz czy wzrósł poziom realizacji testów podstawowych i specjalistycznych tej aparatury.

\section{Materiał i metody}

Materiał pracy stanowiły protokoły z kontroli wykonanych w pracowniach mammograficznych w roku 2007 i 2011 , sporządzone przez fizyków z wszystkich Wojewódzkich Ośrodków Koordynujących (WOK-ów). W 2007 roku skontrolowano w całej Polsce wszystkie aparaty mammograficzne stosowane do badań przesiewowych: łącznie było ich 293. Po czterech latach nastąpił wzrost liczby pracowni mammograficznych wykonujących badania przesiewowe, i w związku z tym w 2011 roku skontrolowano aż 396 mammografów. Zarówno w 2007, jak i w 2011 roku przeważały mammografy z detektorem film-ekran wzmacniający (system analogowy). Jednakże w roku 2011 znacząco wzrosła liczba systemów ucyfrowionych (CR) - z 4 do 52 - oraz systemów cyfrowych (DR) - z 5 do 41. Wzrost liczby mammografów skontrolowanych przez fizyków obrazuje tabela I.

Każdy protokół pokontrolny z roku 2007 i 2011 zawierał informację o posiadaniu przez placówkę aktualnego protokołu z testów specjalistycznych aparatury mammograficznej, które powinny być wykonywane przynajmniej raz na rok przez zewnętrzne laboratoria badawcze $[4,6]$. 
Ponadto podczas każdej kontroli fizycy z WOK-ów oceniali poprawność wykonywania przez techników elektroradiologii testów podstawowych dla systemów analogowych. Sprawdzano, na podstawie przedstawionej dokumentacji oraz bezpośredniej rozmowy z osobami wykonującymi te testy, czy są one wykonywane zgodnie z opracowaniem Komisji Europejskiej „European guidelines for quality assurance in breast cancer screening and diagnosis" [2] oraz Rozporządzeniem Ministra Zdrowia [4, 6].

Każdy protokół pokontrolny zawierał również wyniki testów przeprowadzanych podczas kontroli przez fizyków, zwanych dalej testami w nadzorze. Testy obejmowały między innymi sprawdzenie parametrów związanych z wiązką promieniowania $\mathrm{X}$ i jakością obrazów. Zakres testów oraz kryteria akceptacji wyników przedstawiono w tabeli II. Do przeprowadzania testów w nadzorze fizycy z WOK-ów stosowali jednakową aparaturę pomiarową [8], spełniającą wymagania Komisji Europejskiej [2, 3]. Zakup tej aparatury sfinansowało Ministerstwo Zdrowia. W roku 2007 dla systemów CR i systemów DR nie wykonano testu dotyczącego progowego kontrastu obiektu oraz kompensacji zmian grubości fantomu i wartości wysokiego napięcia przez system automatycznej kontroli ekspozycji, ponieważ nie dysponowano wówczas odpowiednim fantomem do oceny widoczności obiektów o progowym kontraście. Takie fantomy (CDMAM firmy Artinis Medical System BV [9]) zostały użyte do przeprowadzania testów w nadzorze dopiero w roku 2011. Warto zauważyć, że w zaleceniach europejskich opisane są testy dotyczące oceny jakości obrazu dla mammografii ze wszystkimi rodzajami detektorów [2, 3], natomiast polskie prawo, mimo kolejnych nowelizacji, wymaga jedynie testów dla mammografów z detektorem analogowym [4, 6]. Ocena jakości obrazu dla systemów z detektorami CR i DR jest w mammograficznych badaniach przesiewowych pośrednio wymagana przez Narodowy Fundusz Zdrowia [7]. Testy w nadzorze fizycy wykonywali zgodnie z metodami opisanymi w „European guidelines for quality assurance in breast cancer screening and diagnosis" $[2,3]$. Jedynie test dotyczący artefaktów wykonywano zgodnie z opisem zawartym w amerykańskim opracowaniu "Mammography Quality Control Manual" [10]. Wynik testu w nadzorze był zaakceptowany, jeżeli spełniał wymagania podane w tabeli Il $[2,3,10]$.

W niniejszej pracy porównano wyniki pochodzące z wszystkich protokołów pokontrolnych z roku 2007 i 2011, dotyczące realizacji testów specjalistycznych, podstawowych i testów w nadzorze. Szczególną uwagę poświęcono analizie średnich dawek gruczołowych dla ekspozycji rutynowej fantomu o grubości 4,5 cm PMMA. Do analizy różnicy pomiędzy średnią wartością AGD dla wszystkich skontrolowanych systemów mammograficznych w latach 2007 i 2011 użyto jednostronnego testu t (Studenta) na poziomie istotności $\alpha=0,05$, zakładającego nierówne
Tabela I. Zestawienie liczby systemów analogowych, systemów DR i systemów CR skontrolowanych w Polsce w roku 2007 i 2011 przez fizyków z WOK-ów

\begin{tabular}{lcc}
\hline $\begin{array}{l}\text { Sposób rejestracji } \\
\text { obrazu }\end{array}$ & $\begin{array}{c}\text { Liczba } \\
\text { mammografów } \\
\text { skontrolowanych } \\
\text { w roku 2007 }\end{array}$ & $\begin{array}{c}\text { Liczba mammografów } \\
\text { skontrolowanych } \\
\text { w roku 2011 }\end{array}$ \\
\hline $\begin{array}{l}\text { Systemy } \\
\text { analogowe }\end{array}$ & 284 & 303 \\
$\begin{array}{l}\text { Systemy DR } \\
\text { Systemy CR }\end{array}$ & 5 & 41 \\
\hline
\end{tabular}

wariancje. W celu porównania średnich wartości AGD dla systemów analogowych, systemów CR i systemów DR w 2011 zastosowano jednoczynnikową analizę wariancji. Do analizy różnicy pomiędzy średnią wartością $A G D$ dla systemów analogowych i systemów DR oraz systemów DR i systemów CR zastosowano jednostronny test t (Studenta) na poziomie istotności $\alpha=0,05$, zakładającego równe wariancje, natomiast dla systemów analogowych i systemów CR — zakładającego nierówne wariancje.

\section{Wyniki}

W tabeli III podano, ile systemów mammograficznych (z podziałem na systemy analogowe, systemy CR i systemy DR) w latach 2007 i 2011 posiadało aktualny protokół z testów specjalistycznych. Ze względu na małą liczbę systemów CR (4 sztuki) i systemów DR (5 sztuk) w 2007 roku, dane dotyczące tych systemów w tymże roku wyrażono w tabeli poprzez liczby bezwzględne, pozostałe dane wyrażono w procentach z całkowitej liczby skontrolowanych mammografów danego typu w danym roku.

Na rycinie 1 przedstawiono wykaz testów podstawowych wykonywanych w roku 2007 i 2011 w ośrodkach wyposażonych w mammografy z detektorem ekran wzmacniający-film. Przedstawiono również, w ilu pracowniach mammograficznych poszczególne testy wykonywano poprawnie bądź niepoprawnie lub nie wykonywano ich wcale. Wyniki są wyrażone w procentach z całkowitej liczby systemów analogowych sprawdzonych $w$ danym roku.

Na rycinie 2 i rycinie 3 zaprezentowano zestawienie odpowiednio: liczby systemów analogowych oraz systemów CR i DR, dla których spełnione zostały warunki akceptacji poszczególnych testów w nadzorze w latach 2007 i 2011.

Rycina 4 prezentuje wyniki tych testów w nadzorze, których metodyka wykonywania w 2011 roku była jednakowa dla wszystkich typów systemów mammograficznych (bez względu na rodzaj rejestratora obrazu). Podano (procentowo), w jakim udziale z całkowitej liczby skontrolowanych mammografów z danym typem rejestratora obrazu wyniki poszczególnych testów w nadzorze spełniały warunki akceptacji (wymienione w tabeli II). 


\begin{tabular}{|c|c|}
\hline Test & Warunek akceptacji \\
\hline \multicolumn{2}{|l|}{ Geometria wiązki promieniowania X } \\
\hline Kolimacja wiązki — położenie pola promieniowania X względem krawędzi filmu (systemy analogowe) & $\leq 5 \mathrm{~mm}$ \\
\hline $\begin{array}{l}\text { Kolimacja wiązki — położenie pola promieniowania X względem krawędzi wyświetlanego obrazu } \\
\text { (systemy CR i systemy DR) }\end{array}$ & $\leq 5 \mathrm{~mm}$ \\
\hline Położenie krawędzi kratki przeciwrozproszeniowej względem krawędzi filmu (systemy analogowe) & $\leq 4 \mathrm{~mm}$ \\
\hline $\begin{array}{l}\text { Położenie krawędzi kratki przeciwrozproszeniowej względem krawędzi wyświetlanego obrazu } \\
\text { (systemy CR i systemy DR) }\end{array}$ & $\leq 5 \mathrm{~mm}$ \\
\hline \multicolumn{2}{|l|}{ Kompresja piersi } \\
\hline Siła kompresji & $13 \mathrm{~kg} \div 20 \mathrm{~kg}$ \\
\hline Ustawienie płytki uciskowej & $\leq 0,5 \mathrm{~cm}$ \\
\hline Rozdzielczość przestrzenna (systemy analogowe) & $\geq 12 \mathrm{pl} / \mathrm{mm}$ \\
\hline Progowy kontrast obiektu (systemy analogowe) & $<1,5 \%$ \\
\hline Progowy kontrast obiektu (systemy CR i systemy DR) & $<23 \%$ \\
\hline Artefakty & Brak artefaktów \\
\hline $\begin{array}{l}\text { Kompensacja zmian grubości fantomu i wartości wysokiego napięcia przez system AEC (systemy } \\
\text { analogowe) }\end{array}$ & $\leq \pm 0,15 \mathrm{OD}$ \\
\hline \multirow[t]{8}{*}{$\begin{array}{l}\text { Kompensacja zmian grubości fantomu i wartości wysokiego napięcia przez system AEC (systemy CR } \\
\text { i systemy DR) }\end{array}$} & $\begin{array}{l}\text { CNR (w odniesieniu do } \text { CNR }_{\text {limit }} \\
\text { wyznaczonego dla } 5,0 \mathrm{~cm} \text { PMMA): }\end{array}$ \\
\hline & $>115 \%$ dla $2,0 \mathrm{~cm}$ PMMA \\
\hline & $>110 \%$ dla $3,0 \mathrm{~cm}$ PMMA \\
\hline & $>105 \%$ dla $4,0 \mathrm{~cm}$ PMMA \\
\hline & $>103 \%$ dla $4,5 \mathrm{~cm}$ PMMA \\
\hline & $>100 \%$ dla $5,0 \mathrm{~cm}$ PMMA \\
\hline & $>95 \%$ dla $6,0 \mathrm{~cm} \mathrm{PMMA}$ \\
\hline & $>90 \%$ dla $7,0 \mathrm{~cm}$ PMMA \\
\hline Średnia dawka gruczołowa (AGD) dla ekspozycji rutynowej (systemy analogowe) & dla $4,5 \mathrm{~cm}$ PMMA $\leq 2,5 \mathrm{mGy}$ \\
\hline \multirow[t]{3}{*}{ Średnia dawka gruczołowa (AGD) dla ekspozycji rutynowej (systemy CR i systemy DR) } & dla $2,0 \mathrm{~cm}$ PMMA $\leq 1,0 \mathrm{mGy}$ \\
\hline & dla $4,5 \mathrm{~cm}$ PMMA $\leq 2,5 \mathrm{mGy}$ \\
\hline & dla $7,0 \mathrm{~cm}$ PMMA $\leq 6,5 \mathrm{mGy}$ \\
\hline Czas rutynowej ekspozycji & $\leq 2 \mathrm{~s}$ \\
\hline Zgodność wysokiego napięcia & $U_{i}-U_{z} \leq \pm 1,0 k V$ \\
\hline Powtarzalność wysokiego napięcia (systemy CR i systemy DR) & $\left|\mathrm{U}_{s \mathrm{~s}}-\mathrm{U}_{\mathrm{i}}\right| \leq 0,5 \mathrm{kV}$ \\
\hline Luminancja negatoskopu (systemy analogowe) & $3000 \mathrm{~cd} / \mathrm{m}^{2} \div 6000 \mathrm{~cd} / \mathrm{m}^{2}$ \\
\hline Natężenie oświetlenia zewnętrznego negatoskopu (systemy analogowe) & $\leq 50$ lux \\
\hline Ocena wizualna powierzchni negatoskopu & Brak zabrudzeń i zarysowań \\
\hline \multicolumn{2}{|l|}{ Monitory (systemy CR i systemy DR) } \\
\hline Zniekształcenia/artefakty & Brak zniekształceń i artefaktów \\
\hline \multirow[t]{2}{*}{ Widoczność kontrastu } & $\begin{array}{l}\text { Widoczne wszystkie pola o niskim } \\
\text { kontraście }\end{array}$ \\
\hline & Widoczne pola o kontraście 5\% i 95\% \\
\hline \multirow[t]{2}{*}{ Zakres luminancji } & $\mathrm{L}_{\max } / \mathrm{L}_{\min } \geq 500$ \\
\hline & $\begin{array}{l}\text { Różnica maksymalnych luminancji } \\
\text { pomiędzy monitorami należącymi do } \\
\text { jednej stacji opisowej: } \leq 5 \% \text { najniższej } \\
\text { luminancji }\end{array}$ \\
\hline Jednorodność luminancji & $\begin{array}{l}\text { Maksymalne odchylenie luminacji } \\
\text { względem środka monitora: } \leq 30 \%\end{array}$ \\
\hline Natężenie oświetlenia zewnętrznego & $\leq 10$ lux \\
\hline
\end{tabular}

Rycina 5 i rycina 6 przedstawia histogramy średnich dawek gruczołowych dla ekspozycji standardowego fantomu (4,5 cm PMMA) wykonanych w warunkach badań klinicznych. Dane z ryciny 5 dotyczą łącznie wszystkich typów aparatów mammograficznych skontrolowanych w latach 2007 i 2011, natomiast dane z ryciny 6 dotyczą mammografów z roku 2011, z podziałem na systemy analogowe, systemy CR i systemy DR. 
Tabela III. Zestawienie liczby systemów analogowych, systemów CR i systemów DR z aktualnym protokołem z testów specjalistycznych w latach 2007 i 2011

\begin{tabular}{lccc}
\hline & \multicolumn{3}{c}{ Aktualny protokół z testów specjalistycznych } \\
\hline Rok & $\begin{array}{c}\text { Systemy } \\
\text { analogowe }\end{array}$ & Systemy CR & Systemy DR \\
\hline 2007 & $67 \%$ & 3 z & 3 z 5 \\
2011 & $98 \%$ & $100 \%$ & $100 \%$ \\
\hline
\end{tabular}

\section{Omówienie wyników}

W 2011 roku aktualny protokół z testów specjalistycznych posiadały wszystkie skontrolowane w Polsce pracownie mammograficzne z systemem CR i DR, oraz prawie wszystkie pracownie z systemem analogowym (tab. III). Cztery lata wcześniej (w pierwszym roku kontroli skriningu mammograficznego w Polsce) tylko dla około 2/3 skontrolowanych systemów analogowych istniał protokółz testów specjalistycznych (tab. III).

W 2007 roku udział pracowni mammograficznych z systemem analogowym, w których nie wykonywano jakiegoś testu podstawowego, wynosił — w zależności od testu — od 8\% do 45\% (ryc. 1). W 2011 roku tylko w niewielkiej ilości placówek (2\%) poszczególne testy podstawowe nie były w ogóle wykonywane, a udział pracowni, w których poszczególne testy podstawowe wykonywano nieprawidłowo (np. z nieodpowiednią częstotliwością), znacząco zmniejszył się w porównaniu z rokiem 2007. Test dotyczący procesu wywoływania był nieprawidłowo wykonywany w 2007 roku w 21\% placówek, a w roku 2011 - tylko w 7\%. Podobnie było z większością pozostałych testów. Oznacza to, że po czterech latach nastąpiła znaczna poprawa w jakości wykonywania testów podstawowych.

W 2011 roku wzrósł - w porównaniu z rokiem 2007 - udział pracowni mammograficznych z systemem analogowym, dla których zaakceptowano wyniki testów w nadzorze (ryc. 2). Wzrost ten dotyczy wyników każdego z wykonywanych testów. Należy jednak zauważyć, że między 2007 a 2011 rokiem nastąpiły zmiany w metodyce wykonywania dwóch testów, tj. oceny kolimacji wiązki promieniowania $X$ oraz oceny ustawienia płytki uciskowej. Zmiany te mogły mieć wpływ na otrzymywane wyniki. W przypadku testu kolimacji wiązki zmiana polegała na tym, że w 2011 roku nie oceniano zgodności pola promieniowania $X z$ polem filmu wzdłuż krawędzi od strony kolumny mammografu. Położenie pola promieniowania X względem krawędzi filmu dla dużego formatu zaakceptowano w 79\% pracowni (w stosunku do $21 \%$ w roku 2007). Dla testu ustawienia płytki uciskowej różnica polegała na tym, że w 2011 roku oceniano różnicę $\mathrm{w}$ położeniu płytki uciskowej nad stolikiem mammografu między lewą a prawą stroną płytki, natomiast nie brano pod uwagę różnicy w ustawieniu płytki uciskowej między przodem a tyłem płytki. W 2011 roku wyniki tego parametru zaakceptowano aż w 100\% ośrod-

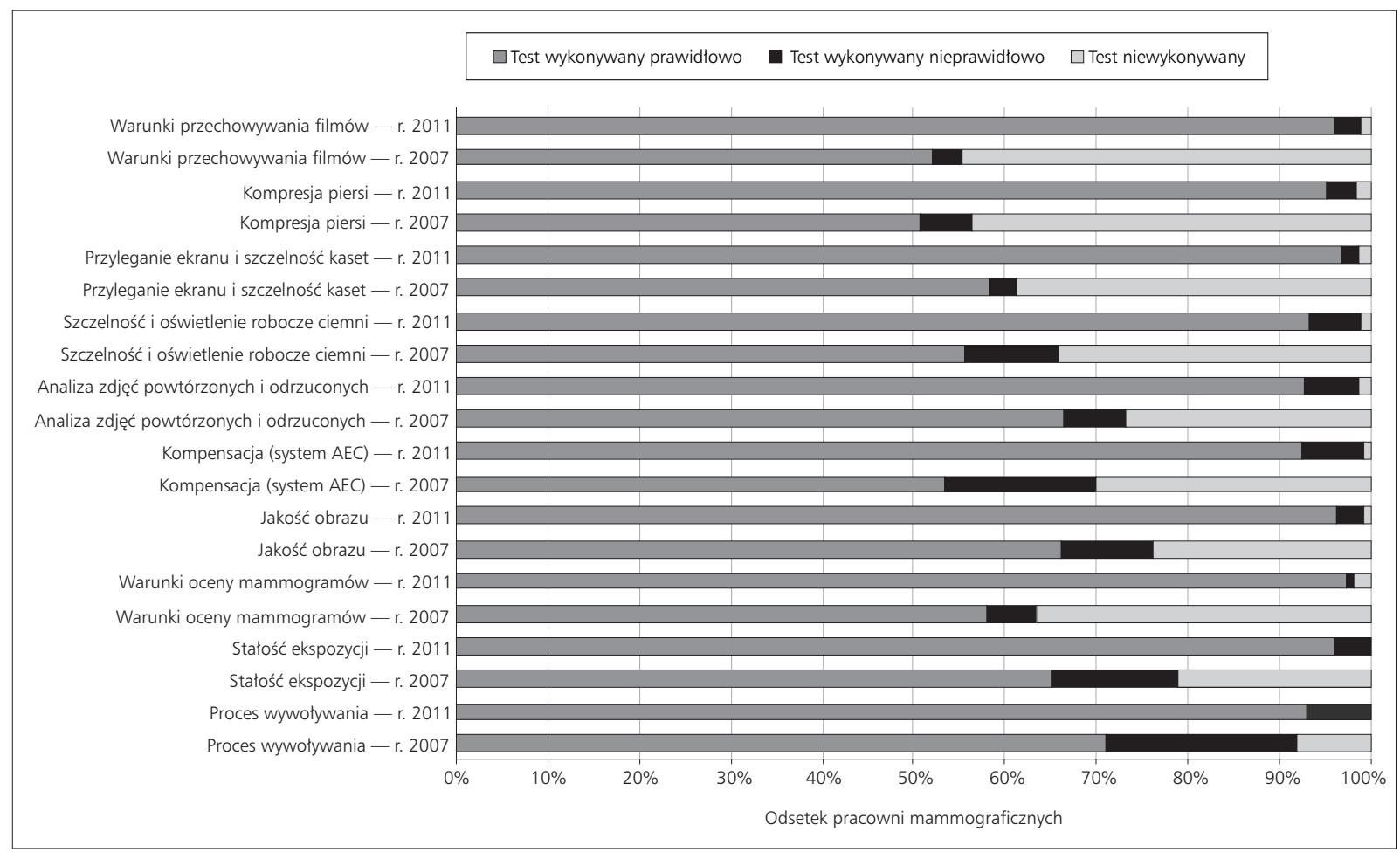

Rycina 1. Zestawienie testów podstawowych, z podziałem na sposób ich realizacji, łącznie dla wszystkich systemów analogowych w latach 2007 i 2011. Kolorem ciemnoszarym oznaczono testy podstawowe wykonywane prawidłowo, kolorem czarnym testy wykonywane nieprawidłowo, a kolorem jasnoszarym — testy w ogóle niewykonywane 


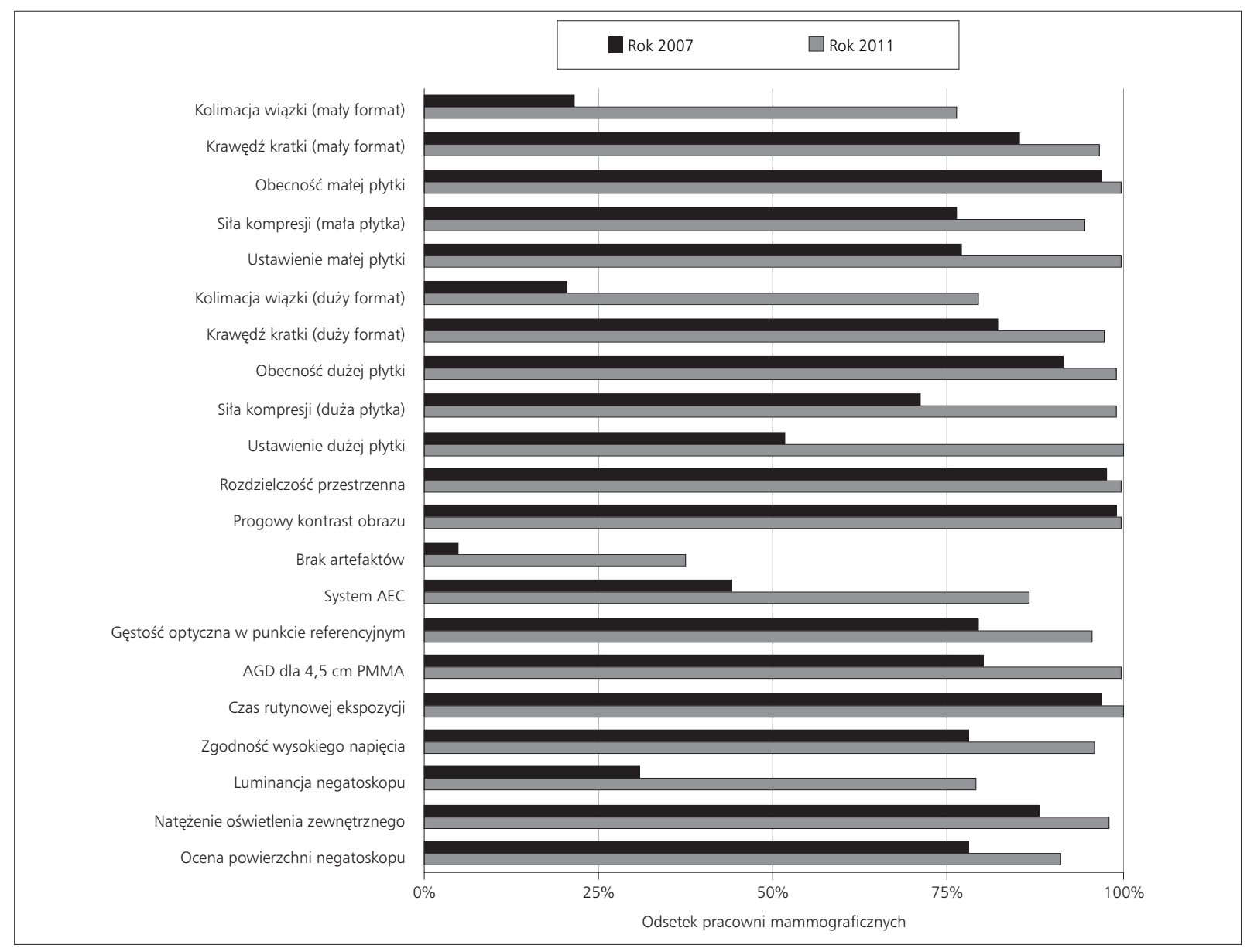

Rycina 2. Zestawienie procentowej liczby systemów analogowych, dla których spełnione zostały warunki akceptacji poszczególnych testów w nadzorze w roku 2007 (kolor czarny) i w roku 2011 (kolor szary)

ków, natomiast w roku 2007 w 77\% przypadków dla małej płytki uciskowej oraz w 52\% przypadków - dla dużej płytki uciskowej. Pozostałe testy były w kolejnych latach wykonywane oraz oceniane według identycznych zasad, a zatem porównanie ich wyników jest w pełni uprawnione. W 2011 roku luminancję negatoskopów zaakceptowano w $79 \%$ pracowni, natomiast w roku 2007 - tylko w $31 \%$, co oznacza znaczącą poprawę tego parametru. W przypadku testu dotyczącego kompensacji zmian grubości fantomu i wartości wysokiego napięcia (system AEC) uzyskano akceptację w 44\% pracowni w roku 2007, podczas gdy w roku 2011 akceptację osiągnięto w 87\%. W 2011 roku, co prawda, nastąpiła poprawa w zakresie testu dotyczącego artefaktów (37\% w porównaniu z 5\% w roku 2007), lecz wciąż wyniki te nie były satysfakcjonujące.

Wyniki testów w nadzorze dla systemów CR i systemów DR w 2011 roku wskazują, że największe różnice między tymi systemami dotyczyły progowego kontrastu, działania systemu AEC oraz położenia pola promieniowania X względem krawędzi wyświetlanego obrazu innych niż od strony klatki piersiowej (ryc. 3). Widoczność obiektów o progowym kontraście została zaakceptowana dla 95\% systemów DR i tylko dla 45\% systemów CR. Miało to również odzwierciedlenie w ocenie systemu AEC — wyniki tego testu zaakceptowano w $97 \%$ systemów DR i tylko w $28 \%$ systemów CR. Warto zauważyć, że niższa jakość obrazu dla systemów CR była także stwierdzana przez innych autorów [11]. Wyniki wszystkich testów dotyczących geometrii wiązki promieniowania $X$, czyli zgodności pola promieniowania $X$ z obszarem detektora obrazu, dla systemów DR zaakceptowano w 91\% przypadków, a dla systemów CR tylko - w 45\%. Część kontrolowanych systemów CR była przedtem wykorzystywana jako systemy analogowe. Być może powodem niskiego odsetka pozytywnych wyników testów dotyczących kolimacji wiązki w tej grupie aparatów jest zmiana rodzaju detektora (z błony rentgenowskiej na płytę obrazową), bez przeprowadzenia regulacji kolimacji wiązki. W obu grupach systemów porównywalna, ale jednak na stosunkowo niskim poziomie była akceptacja zakresu luminancji monitorów służących do oceny obrazów mammograficznych (68\% systemów CR i $63 \%$ systemów DR).

Zestawienie wyników testów w nadzorze wspólnych dla wszystkich typów systemów (ryc. 4) wskazuje, że w 2011 roku w największym stopniu warunki akceptacji 


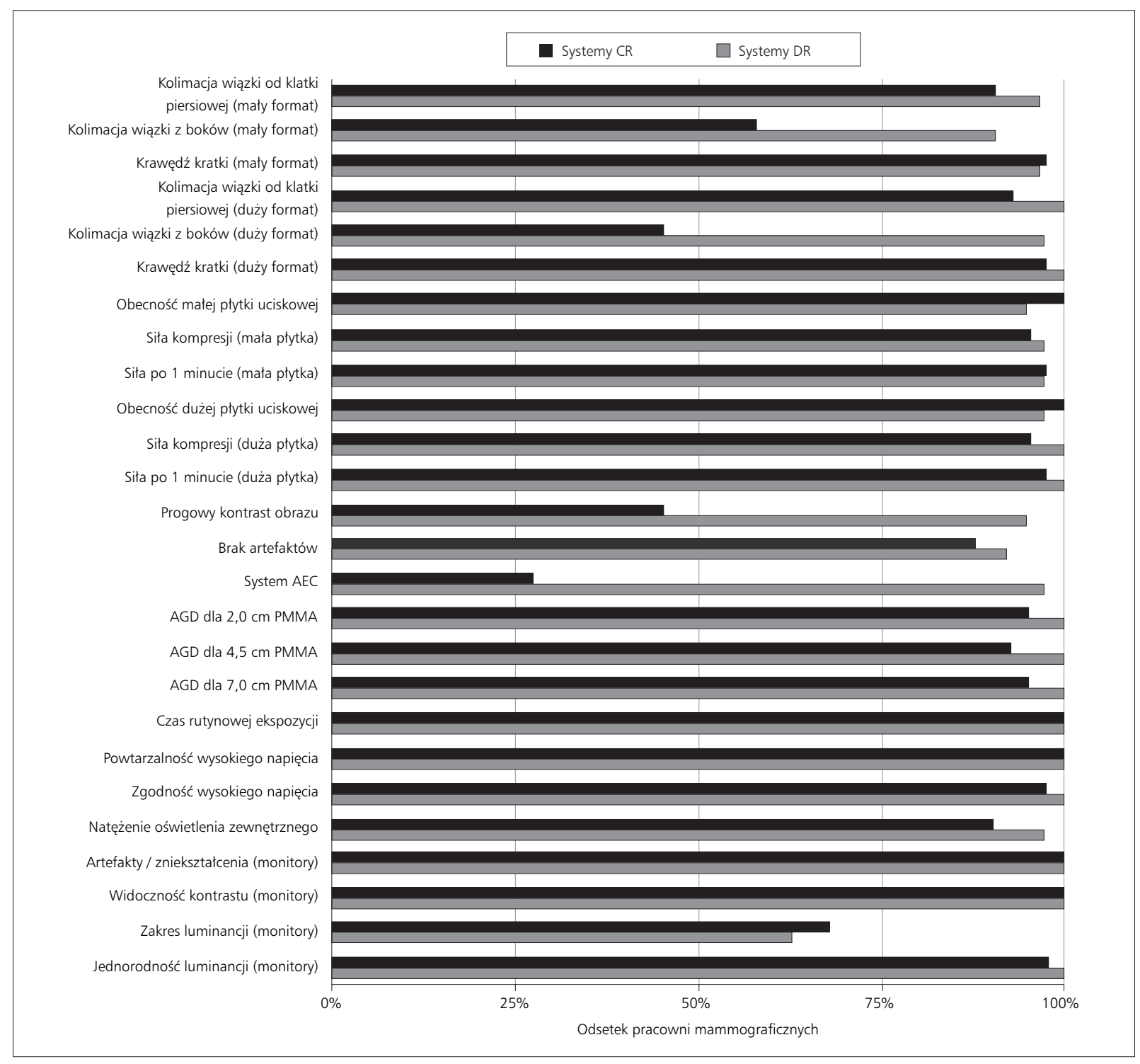

Rycina 3. Zestawienie procentowej liczby systemów CR (kolor czarny) i systemów DR (kolor szary), dla których spełnione zostały warunki akceptacji poszczególnych testów w nadzorze w 2011 roku

spełniały systemy DR (poszczególne wyniki były zaakceptowane dla co najmniej 93\% systemów), a w drugiej kolejności systemy analogowe (akceptacja dla co najmniej 76\%). Najgorzej wypadły parametry systemów CR (akceptacja testu dotyczącego położenia pola promieniowania X względem detektora obrazu tylko dla około 50\% systemów).

W roku 2011 nastąpił spadek maksymalnej wartości średniej dawki gruczołowej (AGD) dla ekspozycji fantomu z PMMA o grubości 4,5 cm o 24\% w porównaniu z rokiem 2007 (ryc. 5). Średnia wartość AGD w roku 2011 była istotnie statystycznie niższa w porównaniu z rokiem 2007 ( $p<0,001$ ). Wyznaczone wartości średniej dawki gruczołowej były mniejsze niż 2,5 mGy w 99\% pracowni w roku 2011. Cztery lata wcześniej udział pracowni mammograficznych z całej Polski, dla których spełniony był limit 2,5 mGy, był mniejszy i wyniósł $81 \%$.
Średnie wartości AGD dla fantomu o grubości 4,5 cm PMMA dla systemów analogowych, DR i CR wyniosły w 2011 roku odpowiednio: 1,40 mGy, 1,64 mGy i 1,87 mGy (ryc. 6). Różnica między wszystkimi systemami była istotna statystycznie $(p<0,001)$. Średnia wartość AGD dla systemów CR była statystycznie znacząco wyższa w porównaniu $z$ systemami analogowymi $(p<0,001)$, wartość średnia AGD dla systemów CR była wyższa w porównaniu z systemami DR $(p=0,01)$, a wartość średnia AGD dla systemów DR była wyższa w porównaniu z systemami analogowymi $(p<0,001)$. Tendencja ta została potwierdzona wcześniej w pracy "Comparison of Individual Doses During Mammography Screening Examinations with Screen - Film and DR Systems and Optimization Attempts of Exposure Parameters" [9]. Odmienną tendencję niż w Polsce zaobserwowano w Norweskim Programie Mammograficznych Badań Prze- 


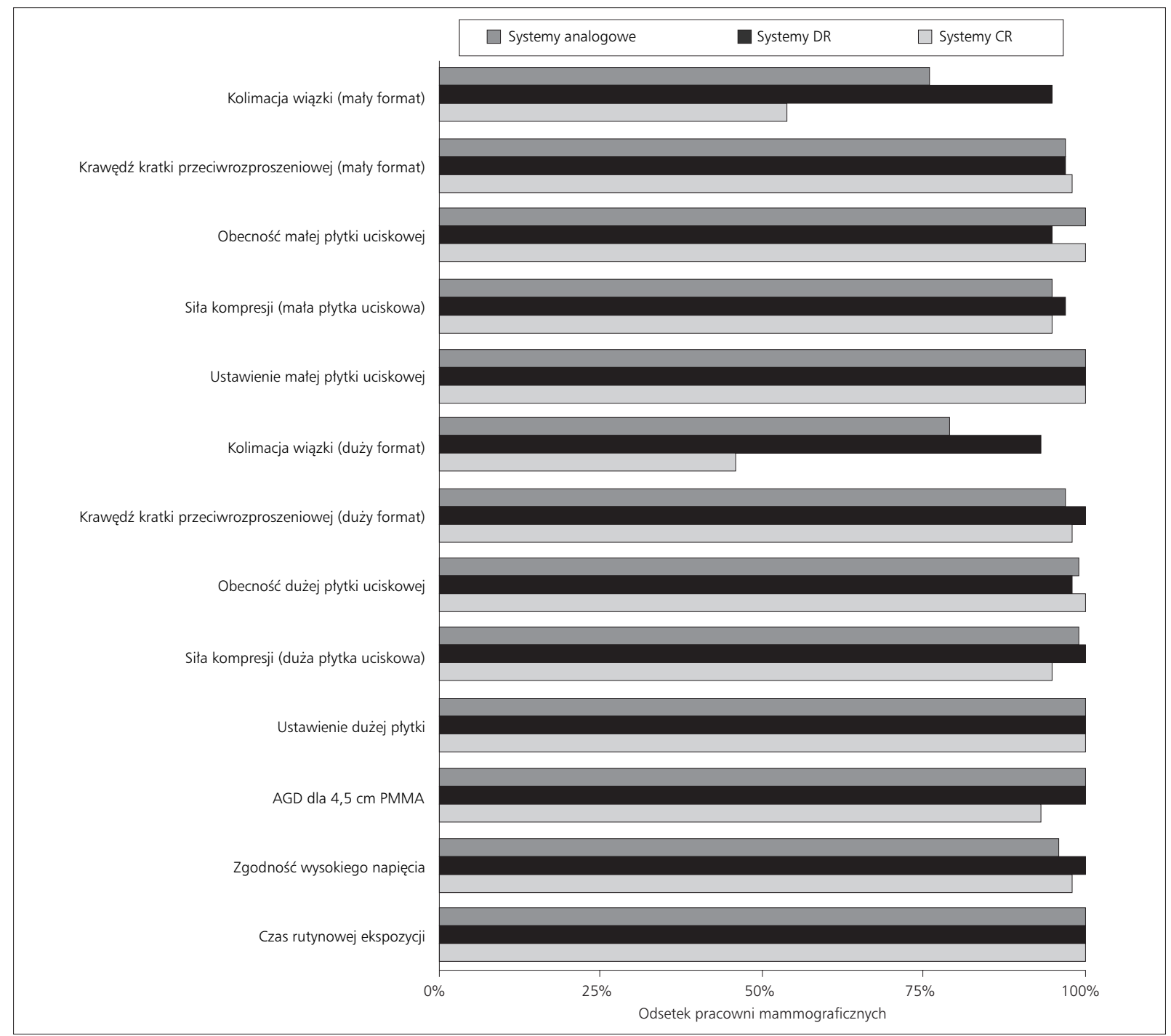

Rycina 4. Zestawienie procentowej liczby systemów analogowych (kolor ciemnoszary), systemów DR (kolor czarny) i systemów CR (kolor jasnoszary), dla których spełnione zostały warunki akceptacji wybranych testów w nadzorze w 2011 roku

siewowych w latach 2007-2009: wartości AGD dla fantomu o grubości 4,5 cm PMMA dla systemów DR były statystycznie znacząco niższe od wartości dla systemów analogowych [12]. Według autorów pracy [9] niższe wartości średnich dawek gruczołowych dla systemów DR można uzyskać, ale po przeprowadzeniu optymalizacji parametrów ekspozycji. Optymalizacja powinna być przeprowadzana zwłaszcza po interwencjach serwisu w oprogramowanie mammografu, w detektor obrazu i inne elementy mogące mieć wpływ na dawkę promieniowania i jakość obrazu.

\section{Wnioski}

Po czterech latach od wprowadzenia w Polsce systemu kontroli jakości badań wykonywanych w ramach „Populacyjnego Programu Wczesnego Wykrywania Raka Piersi" nastąpiła znacząca poprawa stanu aparatury mammograficznej oraz wzrósł poziom realizacji testów podstawowych i specjalistycznych tej aparatury. Sama analiza wyników kontroli nie pozwala na wskazanie przyczyny tej zmiany, nie można jednak wykluczyć, że do poprawy przyczynił się sam fakt systematycznego nadzoru pracowni mammograficznych przez WOK-i.

Do chwili obecnej w polskim prawodawstwie dla mammograficznych systemów ucyfrowionych i cyfrowych nie określono zakresu, metod i wartości granicznych dotyczących testów podstawowych i specjalistycznych, stąd pełna ich ocena $w$ ramach przeprowadzonych kontroli nie była możliwa. W związku z ciągle rosnącą liczbą tego typów systemów w realizacji badań przesiewowych w Polsce konieczne jest jak najszybsze wprowadzenie odpowiednich uregulowań prawnych w celu umożliwienia kompleksowej i rzetelnej oceny wszystkich pracowni mammograficznych.

Wyniki testów w nadzorze, wykonanych w 2011 roku według wytycznych Komisji Europejskiej [3], wskazują na zna- 


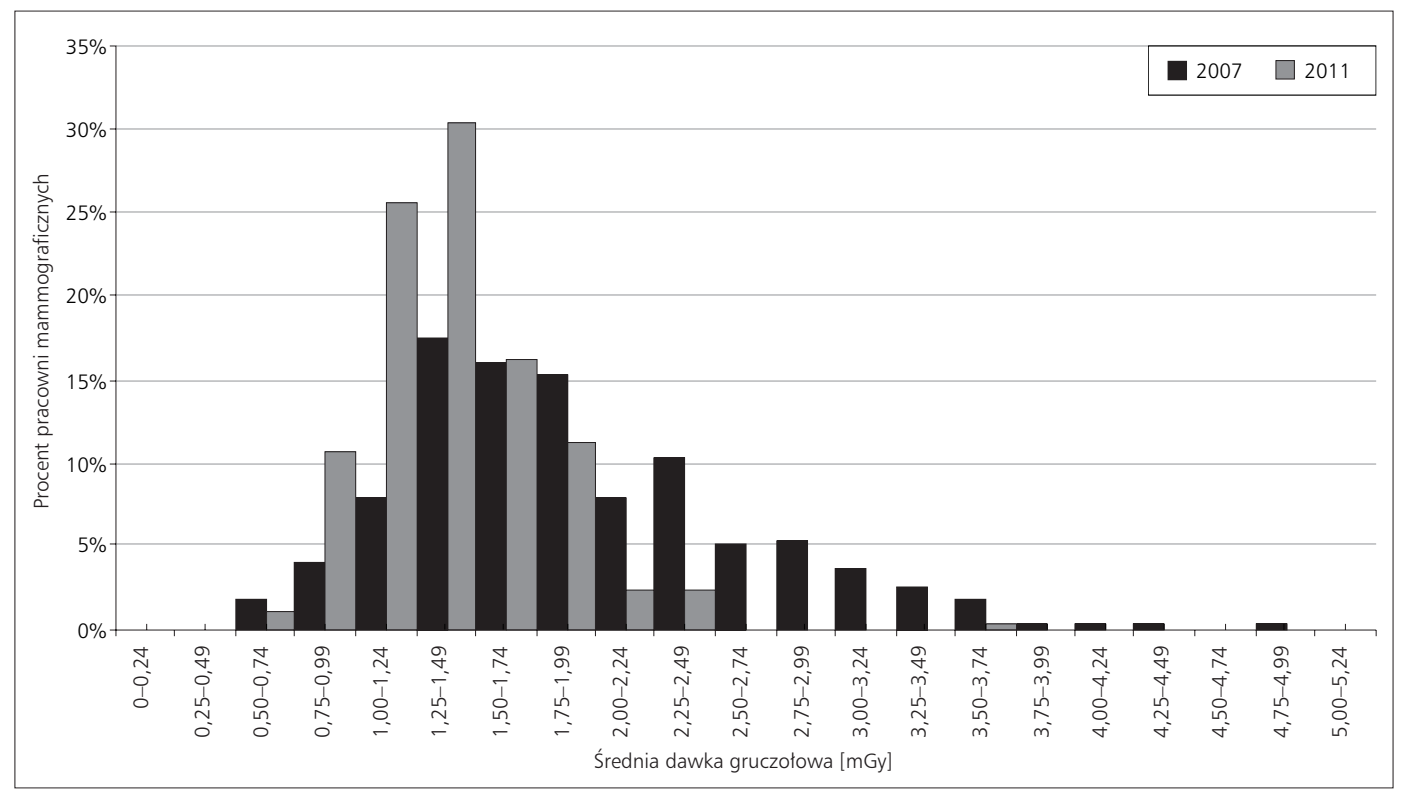

Rycina 5. Histogram średnich dawek gruczołowych (AGD) dla ekspozycji fantomu 4,5 cm PMMA wykonanej w warunkach klinicznych w roku 2007 (wartość maksymalna: 4,76 mGy; wartość minimalna: 0,55 mGy; wartość średnia: 1,93 mGy) i w roku 2011 (wartość maksymalna: 3,63 mGy; wartość minimalna: 0,70 mGy; wartość średnia: 1,48 mGy). Dane dotyczą łącznie wszystkich systemów, tj. systemów analogowych, systemów CR i systemów DR. Górna granica dopuszczalnych wartości to 2,5 mGy

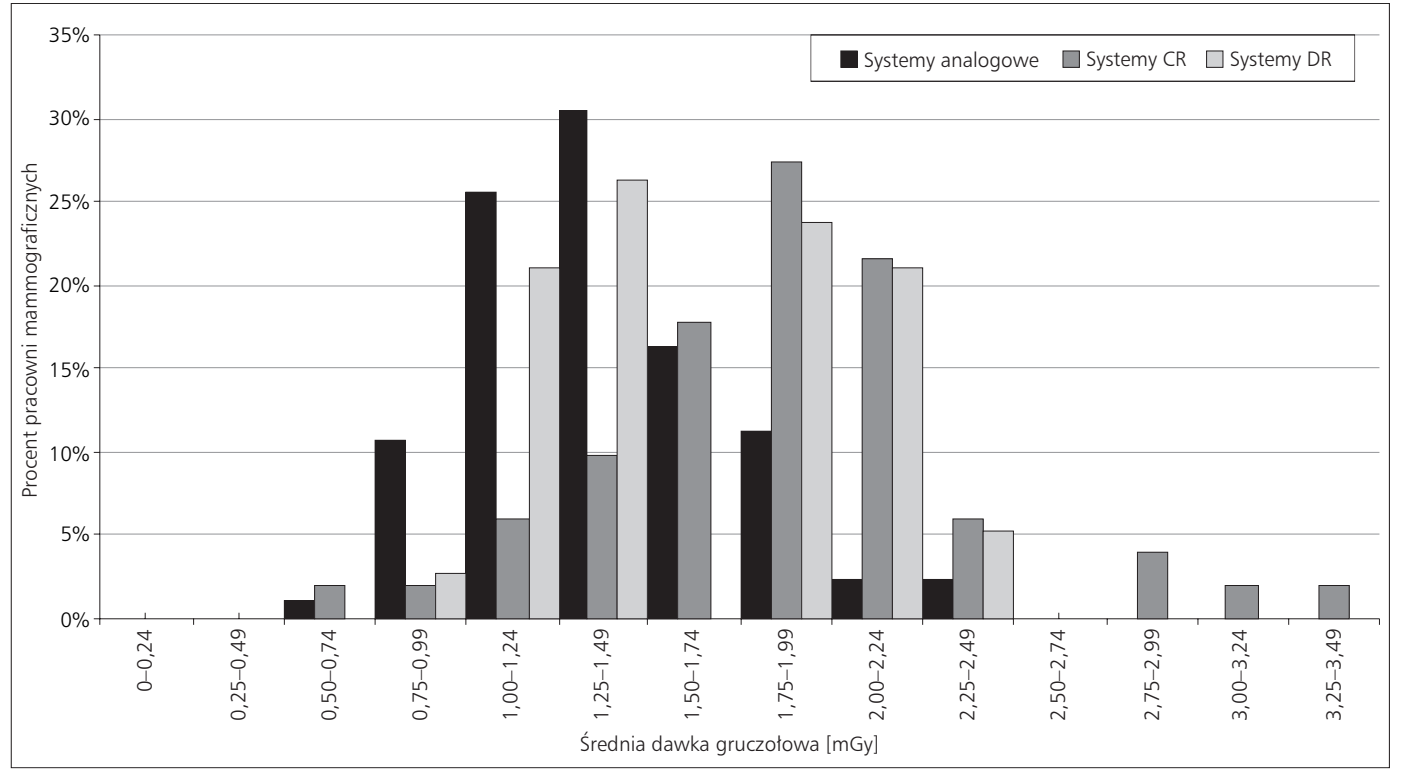

Rycina 6. Histogram średnich dawek gruczołowych (AGD) dla ekspozycji fantomu 4,5 cm PMMA wykonanej w warunkach klinicznych dla systemów analogowych w roku 2011 (wartość średnia: 1,40 mGy), dla systemów CR (wartość średnia: 1,87 mGy) i dla systemów DR (wartość średnia: 1,64 mGy). Górna granica dopuszczalnych wartości to 2,5 mGy

cząco niższą jakość obrazu dla systemów CR w porównaniu z systemami DR przy wyższych dawkach promieniowania X.

\section{Podziękowania}

Autorzy niniejszej pracy dziękują Centralnemu Ośrodkowi Koordynującemu Populacyjne Programy Wczesnego Wykrywa- nia Raka Piersi oraz Profilaktyki i Wczesnego Wykrywania Raka Szyjki Macicy za udostępnienie protokołów z kontroli jakości badań mammograficznych z lat 2007 i 2011.

Autorzy niniejszej pracy sq również bardzo wdzięczni wszystkim fizykom, którzy w ramach działań Wojewódzkich Ośrodków Koordynujących przeprowadzili kontrole w latach 
2007 i 2011 w pracowniach mammograficznych realizujących badania przesiewowe w Polsce.

\section{Konflikt interesu: nie zgłoszono}

\section{Dr n. med. Ewa Fabiszewska}

Zakład Fizyki Medycznej

Centrum Onkologii — Instytut im. Marii Skłodowskiej-Curie

ul. W.K. Roentgena 5, 02-781 Warszawa

e-mail:e.fabiszewska@zfm.coi.pl

Otrzymano: 17 maja $2013 \mathrm{r}$.

Przyjęto do druku: 9 lipca 2013 r.

\section{Piśmiennictwo}

1. Uchwała Nr 47/2006 Rady Ministrów z dnia 4 kwietnia 2006 roku w sprawie harmonogramu zadań wykonywanych w ramach programu wieloletniego "Narodowy program zwalczania chorób nowotworowych" w roku 2006 oraz kierunków realizacji zadań tego programu na lata 2007 i 2008.

2. van Engen $\mathrm{R}$, van Woudenberg $\mathrm{S}$, Bosmans Hi wsp., European protocol for the quality control of the physical and technical aspect of mammograhy screening Screen-film mammography. W: Perry N, Broeders M, de Wolf C i wsp. (red.) European guidelines for quality assurance in breast cancer screening and diagnosis. Wyd. 4. Luxembourg, Belgium: Office for Official Publications of the European Communities; 2006, 61-104.

3. van Engen $\mathrm{R}$, Young $\mathrm{K}$, Bosmans $\mathrm{H}$ i wsp., European protocol for the quality control of the physical and technical aspect of mammograhy screening Digital mammography. W: Perry N, Broeders M, de Wolf C i wsp. (red.) European guidelines for quality assurance in breast cancer screening and diagnosis. Wyd. 4. Luxembourg, Belgium: Office for Official Publications of the European Communities; 2006, 105-150.

4. Rozporzadzenie Ministra Zdrowia z dnia 25 sierpnia 2005 roku w sprawie warunków bezpiecznego stosowania promieniowania jonizującego dla wszystkich rodzajów ekspozycji medycznej. Dz. U. Nr 194 poz. 1625

5. Rozporządzenie Ministra Zdrowia z dnia 21 sierpnia 2006 roku w sprawie szczegółowych warunków bezpiecznej pracy z urządzeniami radiologicznymi Dz. U. Nr 180 poz. 1325.

6. Rozporządzenie Ministra Zdrowia z dnia 18 lutego 2011 roku w sprawie warunków bezpiecznego stosowania promieniowania jonizującego dla wszystkich rodzajów ekspozycji medycznej. Dz. U. Nr 51 poz. 265.

7. Zarządzenie Nr 57/2009/DSOZ Prezesa Narodowego Funduszu Zdrowia z dnia 29 października 2009 r. w sprawie określenia warunków zawierania i realizacji umów w rodzaju profilaktyczne programy zdrowotne (wraz z późniejszymi zmianami).

8. Fabiszewska $E$, Evaluation of the mammography screening examinations in Poland in 2007- results of quality control tests. Nowotwory J Oncol 2008; 58: 521-529.

9. Fabiszewska E, Pasicz K, Grabska l i wsp. Comparison of Individual Doses During Mammography Screening Examinations with Screen - Film and DR Systems and Optimization Attempts of Exposure Parameters. W: Nachiko Uchiyama, Marcelo Zanchetta do Nascimento, (red.) Mammography Recent Advances. Rijeka: INTECH; 2012, s.109-132.

10. Hendrick RE, Bassett L, Botsco MA i wsp. (red.). Mammography Quality Control Manual. Reston, VA: American College of Radiology; 1999.

11. Oberhofer N, Fracchetti A, Springeth M, Moroder E, Digital mammography - DQE versus optimized image quality in clinical environment: an on site study. Proc. SPIE 7622, Medical Imaging 2010: Physics of Medical Imaging, 76220J.

12. Pedersen $\mathrm{K}$, Landmark ID, Bredholt Ki wsp. Phantom Dose Levels Found at Annual Physics Surveys in a National Mammography Screening Program: Comparison of Doses from analog and Digital Equipment and from Digital Equipment at Different Points in Time. W: Marti J, Oliver A Freixenet J, Marti R, (red.) Digital Mammography. Berlin Heidelberg: Springer-Verlag; 2010, s. 100-105.

W dniach 15-17 maja 2014 roku odbędzie się w Bydgoszczy

\title{
XX Zjazd Polskiego Towarzystwa Chirurgii Onkologicznej
}

\author{
Organizatorzy: \\ Polskie Towarzystwo Chirurgii Onkologicznej \\ Katedra i Klinika Chirurgii Onkologicznej CM UMK \\ Centrum Onkologii im. prof. F. Łukaszczyka w Bydgoszczy \\ Główne tematy: \\ - leczenie skojarzone nowotworów \\ — indywidualizacja leczenia onkologicznego \\ - leczenie chorych w wieku podeszłym
}

Miejsce obrad:

OPERA NOVA

ul. Focha 5, 85-070 Bydgoszcz

Informacja i rejestracja:

http://www.20zjazdptcho.pl 